\title{
Introduction of the American Pediatric Society's 2005 John Howland Award Recipient, Mary Ellen Avery, M.D.
}

\author{
MARGARET K. HOSTETTER \\ Department of Pediatrics, Yale University School of Medicine, New Haven, Connecticut 06520
}

Mary Ellen Avery (Fig. 1) was born on May 6, 1927, in Camden, New Jersey. APGARs were 10 at $1 \mathrm{~min}$ and 11 at 5 . Having gotten off to a fast start, Mel decided not to walk until 19 months of age. As her mother recorded in her baby book, "Suddenly one Sunday afternoon she stood up and stepped out. Having discovered she could walk, she kept steadily at it." How well do these early months portend the rest of the career! HAVING DISCOVERED, SHE KEPT STEADILY AT IT.

Growing up in Moorestown, New Jersey, Mel was inspirited by her father William, who founded a manufacturing plant in Philadelphia, and by her mother, Mary, who was principal of a high school in Newark when she married. Next-door neighbor, Emily Bacon, M.D., a graduate of Johns Hopkins Medical School and Professor of Pediatrics at Women's Medical College, amplified the influence of the nuclear family. Mel was inoculated early with the medicine bug when Dr. Bacon took her to see a premature baby. As Mel described to Marsha Angell in a 1992 interview for Leaders in American Medicine, a monograph sponsored by Alpha Omega Alpha, "All through high school I was talking about going to medical school, and with the support of my parents, I had an opportunity to do everything I wanted to do."

Beginning in 1935, family vacations in Maine-Mel, her parents, and big sister Jane (Fig. 2) — set in motion a deeprooted attachment to our nation's northernmost state that has lasted for 70 years. Indeed, many of Mel's recollections begin, "Driving back from Maine, I stopped off to see . . . Jere Mead, or Clem Smith," or a host of other seminal figures.

At Wheaton College in Massachusetts, "I got a lot of positive reinforcement," recalled Mel, but that seems an understatement compared with the encomia in the Wheaton News

Received July 14, 2005; accepted July 15, 2005.

Correspondence: Margaret K. Hostetter, M.D., Department of Pediatrics, Yale University School of Medicine, New Haven, Connecticut 06520-8064; e-mail: Margaret. Hostetter@yale.edu

Presented at the 2005 Annual Meeting of the Pediatric Academic Societies, Washington, D.C.

DOI: 10.1203/01.pdr.0000189312.67186.d8

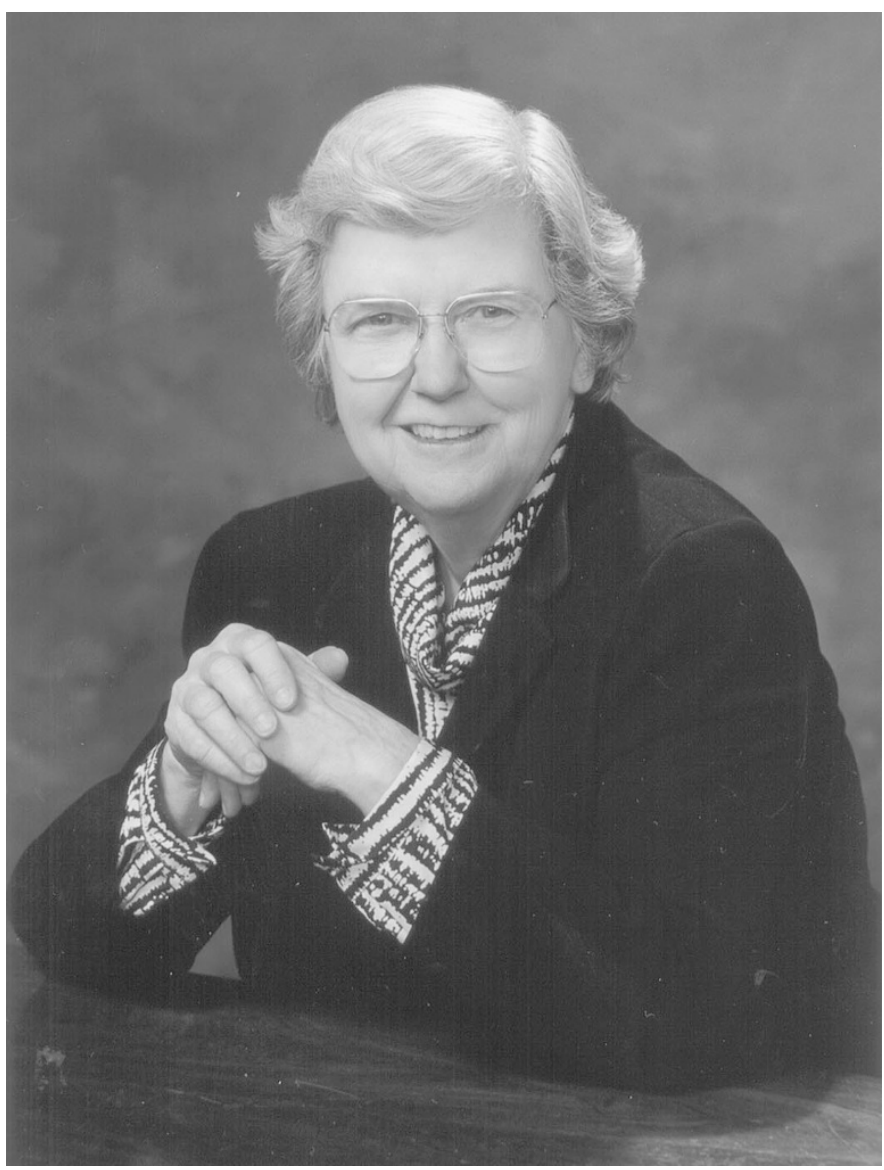

Figure 1. Dr. Mary Ellen Avery

of February 1948. A junior Phi Beta Kappa and summa cum laude graduate in chemistry, Mel did her honors thesis on radioactive isotopes while playing hockey, badminton, and baseball throughout college. Getting almost equal billing in this article is Eureka, Mel's somewhat recalcitrant Plymouth sedan. 

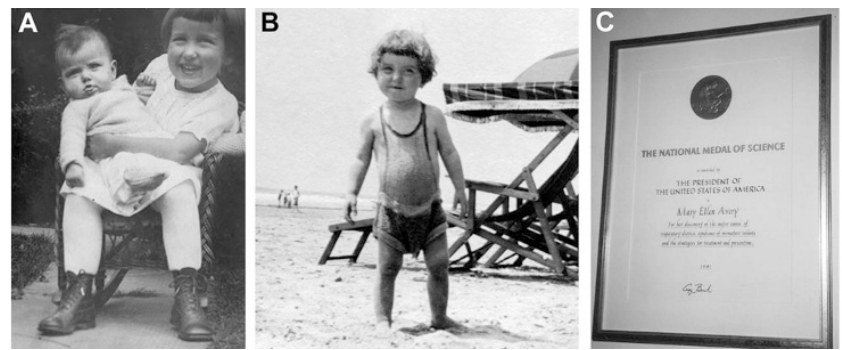

Figure 2. (A) Dr. Avery's favorite picture with her big sister Jane. (B) Dr. Avery on the beach at age two. $(C)$ The National Medal of Science.

Mel applied to two medical schools: Harvard and Johns Hopkins. As Mel put it in Leaders in American Medicine, "Harvard didn't take women at that time but I didn't know it, and Johns Hopkins did. In fact, they had to. They were founded by Mary Elizabeth Garrett, who had insisted that they wouldn't get the money to build the school if they didn't take women on an equal basis with men. Emily Bacon graduated from Johns Hopkins. So there was no question where I was going to go to medical school." One of four women in a class of 90, Mel recalled, "I loved medicine as I thought I always would. At last there I was, learning the things I wanted to know, and I felt supported at every level."

Beginning her internship at Johns Hopkins, there was no question that pediatrics would be her focus. Pictures show Mel and her mother outside the hen house at 800 North Broadway, where all the female medical students and residents lived. However, after just one month, Mel's address changed precipitously. A positive tuberculin test landed her in bed for 6 months. She signed herself out of Saranac Lake and took her PAS and streptomycin at home. As she recalls, "Every day in bed I thought about LUNGS . . . and I realized at the time that a lot of medicine was preached with great conviction and with very little scientific basis, so I decided that maybe there was room for somebody to put some underpinnings in there."

After about eight months, she returned to her internship at Johns Hopkins and noted in the nurseries that premature infants were dying of a lung ailment called hyaline membrane disease. The commonality among these infants was atelectasis, not aspirated material, and Mel badgered Richard Riley, her pulmonary prophet, and asked, "What would you do if you wanted to learn more about babies' lungs?" and he said, "Go talk to Jere Mead."

So one day, returning from her summer place in Maine, she stopped off to meet Jere Mead at the Harvard School of Public Health, Department of Physiology, and walked across the street to see Clement Smith at the Boston Lying-In. As Mel remembers, "Jere Mead was telling me things I didn't know anybody knew, and they were very exciting." At the end of her residency, Mel began her joint fellowship with Clement Smith and Jere Mead in 1957.

Jere Mead, it turned out, was working on a research contract with the Army Chemical Center, trying to understand how certain chemical agents caused pulmonary edema. And assigned by the military to monitor the Harvard contract was none other than John Clements. As Dr. Avery recalls, Clements had brilliantly modified a Langmuir-Wilhelmy balance to measure surface-active material from lung tissue.

Just weeks after Clements' report that lung extracts contained a stabilizing material, he was visited by Mel. Mel and Mead initially reproduced the balance but not the results, so Clements came to Boston to provide technical insight. The error corrected, by December 1958, Mel and Jere Mead submitted the first paper reporting that surfactant was absent from the lungs of infants under $1,100 \mathrm{~g}$ and from those dying with hyaline membrane disease.

The impact of this paper was explosive. Investigators rushed into the field, and like a rocket's arc, Mel's discoveries in morphology, cell biology, and the physiology of the fetal lamb showered the field with the sparks for surfactant replacement therapy.

In the scant six-year period between 1959 and 1965, while a fellow in Boston and Assistant Professor and chief of the newborn nurseries at Hopkins, she published 23 classic papers on neonatal respiratory physiology in Science, Nature, The Journal of Clinical Investigation, and The New England Journal of Medicine. Her stature in the discipline is evident from a 1966 photo at Hopkins, with assistant professor Mel clearly the young Turk in the midst of elder luminaries: Clement Smith, Margaret Kemball, Roy Tiernon, Richard Bay, Chris Nourse, John Bucci, and Nick Nelson. HAVING DISCOVERED, SHE KEPT STEADILY AT IT.

Branching morphogenesis of the lung has its parallels in this, the tree of modern neonatology. From the root of Clement Smith have sprouted some of the most remarkable figures in $20^{\text {th }}$ century pediatrics, including Jack Rudolph and Mel. The Avery branch, in particular, leafs out with Marc Beem (Chicago), Dav Cook (Yale), Peter Auld (Cornell), James Sutherland (Cincinnati), and Nick Nelson, whose mother designed this heraldic tree of life.

As an Associate Professor at Hopkins in 1969, Mel was tapped to become Professor of Pediatrics at McGill and Chairman of the Montreal Children's Hospital. But after just four years in Montreal came the call from Harvard, to be Physicianin-Chief of the Children's Hospital and Thomas Morgan Rotch Professor of Pediatrics at Harvard Medical School. Those who know Mel understand that there was but one fundamental principle impelling her move to Boston in 1974.

Carl Yastremzeski, Rico Petrocelli, Carlton Fisk, Dwight Evans, wildman Freddie Lynn, and Jim Rice-what a team! Not to be outdone, Mel opened her own ballpark in the Prouty Garden, and the home team always wore white. Avery pitching; Janeway at the plate; Rosen, Shwachman, and Grand on the bases; Lovejoy at shortstop; and Lux, Parkman, and Nathan in the field.

Up from the minors came more than a decade of fresh young pediatricians, many to emulate their chairman by becoming section chiefs or department chairs throughout the country. One of her residency classes in 1976 includes three section chiefs, three pediatric chairs, and the president of the Institute for Healthcare Improvement. At last count, among her 271 interns are two presidents and CEO's, two HHMI investigators, two institute directors, two National Institutes of Health branch 
chiefs, 2 associate deans, 9 holders of endowed chairs, 6 pediatric department chairs, and 42 section chiefs.

So what was it like, coming to Boston Children's in 1975 with the first woman chair in Harvard history? Exciting wasn't the word for it. Limitless possibilities- that was more like it - the sense that we could travel as far as our imagination led us, even to the maternity ward. Here are the first three babies born to female Children's residents-two neonatologists and one apostate. Mel didn't have to deliver a baby; she delivered the message. AND HAVING DISCOVERED, SHE KEPT STEADILY AT IT.

Establishing the Joint Program in Neonatology, Mel and the 74 trainees on this slide expanded the reach of the discipline. On the heels of The Lung and its Disorders in the Newborn Infant, a classic in the field for 25 years, came Pediatric Medicine, edited with Lewis First. Avery's Diseases of the Newborn, her third textbook, is now in its 8th edition.

At almost the same time, Mel began her crusade for better care for newborns the world over. More than two decades of volunteer work with UNICEF have made her, in the words of Sam Katz, the world's best known pediatrician. Her international missions have taken her from Baffin Island to Nairobi, from Cuba to Turkey to Trieste, from Singapore to Samarkand. And these are not merely ceremonial visits. In virtually every country, Mel conducted detailed evaluations of pediatric care and established or improved access to medical care for the world's children.

Is it any wonder that her colleagues would recognize her with election as the first female President of the Society for Pediatric Research (1972-1973) and President of the American Pediatric Society (1990-1991)? Early scientific honors have included the John and Mary Markle Scholar in Medical Science, the E. Mead Johnson Award from the Society for Pediatric Research, and the Edward Livingston Trudeau Medal from the American Lung Association. In later years, her sterling accomplishments have won for her the Walsh McDermott Medal from the Institute of Medicine, the Virginia Apgar Award from the American Academy of Pediatrics, and the Franklin Delano Roosevelt Award from the March of Dimes. She has received 16 honorary degrees in the United States and abroad. She is a member of the Institute of Medicine, the American Academy of Arts and Sciences, and the National Academy of Sciences.

And HAVING DISCOVERED, SHE KEPT STEADILY AT IT with not one but two capstones: the National Medal of Science awarded by President Bush in a White House ceremony in 1991 and the presidency of the American Association for the Advancement of Science in 2004 - in both cases, the first pediatrician to be so honored.

In closing, let us hear what some of the most revered figures in pediatrics have to say in their letters supporting her nomination:

From Robert J. Haggerty, Professor and Chair Emeritus at the University of Rochester:

"For 10 years she chaired the Robert Wood Johnson Foundation's National Advisory Committee for the General Pediatrics academic program. It was in large part due to her leader- ship that rigorous research training was the major basis of this fellowship."

From Rebecca Buckley, J. Buren Sidbury Professor of Pediatrics at Duke:

"The announcement that she had been named Chairman of the Department of Pediatrics at Boston Children's in 1974 demonstrated to many women physicians that the 'glass ceiling' can be broken."

From Robert B. Mellins, Professor of Pediatrics, The College of Physicians and Surgeons of Columbia University:

"I single out her recent position as President of the American Association for the Advancement of Science to indicate her stature in the larger field of American science."

From Roberta Ballard, Professor of Pediatrics at the University of Pennsylvania:

"She has played a crucial role in the wide clinical acceptance of the two most important contributions of the past 20 years for preventing and treating hyaline membrane disease in the newborn infant: antenatal steroids and surfactant replacement."

From Ivan Frantz, III, David and Leona Karp Professor of Pediatrics at Tufts New England Medical Center:

"The observation she made as a fellow in 1959-that insufficiency of surfactant was responsible for hyaline membrane disease-was probably the most significant observation in all of neonatology."

From Jerold F. Lucey, Professor of Pediatrics at the University of Vermont:

"It is the major advance in neonatal care in the last 50 years."

From Victor Chernick, Professor Emeritus of The Children's Hospital at Winnipeg:

"Her discovery led to the saving of countless lives of prematurely born infants throughout the world."

From Emily Bacon to Emily's List, from the children of Maine to the children of Peru, from Bar Harbor to the bar graph of neonatal mortality, Mary Ellen Avery's contributions to pediatrics transcend the constraints of time and the boundaries that others would set for us. It is she who hoists the banner for the world's smallest and most vulnerable citizens, she who will not let the world forget that our future rests in the hands of our children.

Colleagues of the Pediatric Academic Societies, I give you the 2005 John Howland Award Recipient, Dr. Mary Ellen Avery.

Acknowledgments. The author thanks Drs. Sam Hawgood, Fred Lovejoy, Martha Magoon, Nick Nelson and Brenda Papke and the archives of the American Pediatric Society for contributing photographs to the introduction presented on Sunday, May 15, 2005.

Remarks made at the John Howland Award Dinner held Sunday, May 15, 2005 in honor of Mary Ellen Avery, M.D.

It's a daunting task to stand before you luminaries and describe in five minutes (without slides) my experience of Mel over the past 35 years. 
How to begin? Dr. Hostetter gave a full-on description of Mel's career this morning.

I didn't do any homework, so I'll just give some personal reminisces from her Montreal era.

When I signed on to work with her as a fellow in 1969, she was working on (what at the time) were the two most boring subjects in all of medicine-pulmonary physiology (the science of memorizing lung volumes) and steroid biochemistry (more memorization, of formulas resembling chicken wire).

But the 60's had been an exciting time in neonatology and many of the discoveries from that time were captured in sequential editions of Mel's book that she referred to, in shorthand, as THLADNI, or, more elegantly, The Lung and Its Disorders in the Newborn Infant.

I think it best to summarize a few of the lessons she has taught me over the past nearly 40 years, but more particularly, to illustrate how she taught them, her heuristic technique if you will.

Lesson 1. Academic pressure. When I, as a brand-new fellow in neonatology, entered her lab in the Macintyre Medical Building at McGill, no one was there. Her office was three miles away in Montreal Children's Hospital. When I told her I didn't know what to do or who to do it with, she said, "You know, Bill. I'm giving you all the space, all the time, and enough money. Now do something."

Lesson 2. Generosity. Dr. Enhorning was coming to Montreal to visit our lab. I asked Mel if I should tell him all of what we were doing. She looked stunned and asked why not? I shuffled and muttered that maybe he would, perhaps, make off with some of our current ideas. She looked at me, as only she could look at one under these sorts of circumstances, and said, "You know, Bill. He won't. And, you may have some more ideas where those came from."

She was not altogether naïve about taking credit though. When three of us collaborated on a paper with her, she said, "You know, Bill. I don't care where you list me as coauthor. With names like Taeusch, Wysogrodski, and Kyei-Abogyi, Avery is the only one anybody will remember."

Lesson 3. Style versus Substance. In my first year in Montreal, before we were joined in the lab by Drs. Thach, Frantz, Adler, and others, she would come regularly for two to three hours every Wednesday afternoon for a seminar with me, ... nose to nose. Once, when she asked me what I had done over the past week, I gave her a short answer about doing a few runs on the surface balance. She pushed her glasses back up her nose, looked at her watch, and said, "I'll be going back to my office at five, and by six I'll have done more in an hour than you've done all week!"

I became a little testy and delivered a full paragraph about all the research knots I had indeed untangled during the past few days. When I ran out of steam, she nodded and smiled, and said, "You know, Bill. You not only have to do well. On occasion you have to show that you are doing well."

And finally, Lesson 4. Mentorship. Mel continues to take an interest in many of us, and for me she has been a mentor for life. This lesson was reinforced recently on the publication of the $8^{\text {th }}$ edition of Avery's Diseases of the Newborn. A number of you in the audience worked hard on this last edition and I had the honor of writing the preface. When I knew Mel had received her copy, I called her to share good feelings about completion of the book. Her first comment was, "Who's the idiot who misspelled Schaffer's name in the preface?"

So now some feedback for my mentor.

You know, Mel. We all thank you for the influence you've had on us, on pediatrics, and on kids, the world over.

H. William Taeusch, M.D. Professor and Vice Chair of Pediatrics University of California San Francisco San Francisco General Hospital

Despite going second, I am delighted that I have the honor of truly being the "first" speaker to salute Mel on winning the Howland Award. While I know you heard this morning so much about what earned her this award, I'm not sure Mel or I would be here tonight if not for our friendship over the years. For example-let's take some of her most noteworthy publications and how they came to be-

For example there was the 1966 paper in JPeds vol 68 (no 6)-p. 1008-1010 in regard to my mother's decision as to whether to breast or bottle feed entitled "The First Drink Reconsidered." Then there was the problem I had getting out of the gate in the DR-which Mel wrote about in 1969 in the American Review of Respiratory Disease 1003(3)—p. 295304. entitled "The First Breath" and the rest as you know is surfactant history.

Well since then the rest is history, I must say there is probably no one in this room or who has embarked upon a career in pediatrics who has not done so because of Mel's influence in one way or another-as a clinician, as an investigator, as a teacher, and/or as an advocate for children and families all over the world.

While all of you here tonight may relish Mel's contributions to pediatric science, I relish the special time and many conversations we have had together on everything from baseball to knock-out mice. In fact Mel has shared with me so many memorable statements that I thought I would share my top ten quotations from Chairman Mel:- statements she has made to me over the years that have influenced my own career in pediatrics.

Going from 10 to $1, \# 10$ occurred as a medical student on my first clerkship in Pediatrics when she saw me blowing soap bubbles with a child in the play room as a medical student and said, "Have you ever considered becoming a pediatrician"obviously knowing I was already experimenting with lung physiology. That led me to refocus my career from what was going to be either internal medicine or surgery, and I'm glad I did.

Statement \#9 followed two years later. It was when I was a second year resident and overheard her examining one of my continuity clinic patients that had been admitted for failure to thrive. Not knowing I was behind her she turned to the ward senior and plainly stated-“Who is this child's resident? I can't 
believe this person has a license to practice!" Which brings me to

Statement \#8-upon discovering it was one of her house staff whom she had selected to be one of her future chief residents-i.e., me-she paused and said-well that's why it's a three year training program and in your case four will do you just fine.

Statement \#7-I believe occurred for many of us in the room who had the chance to learn from her as a ward attending. It is a very simple statement that rings as clearly today as it did more than 20 years ago- - Who put these children into those mist tents and are there even children inside those tents? I have no idea since I can't see anything going on in there with all that mist!"

Statement \#6-was memorable because it reflects Mel's ability to predict the future. I will never forget meeting with her as a senior resident and having her tell me "There is no question about it-you are destined to be a neonatologist." I think some of you also heard that statement from her-and while it has proved to be the destiny of thousands of pediatric residents who wanted to further the discoveries and advance the science in this field, it turned out not to be mine.

Which brings me to memorable statement \#5-which occurred when I told her I didn't want to be a neonatologist but a general pediatrician - and you can imagine how warm and toasty I felt when she paused, smiled, and then said "Well, I guess if someone is going to make an impression in general pediatrics, it might as well be you."

The beauty of that statement was her wanting me and everyone else to not just stand there but "do something"- and it was here that I realized how much of a risk taker and doer Mel really was, especially when I became her chief resident and to me in memorable statement \#4-"Have you ever tried writing a textbook?" Not having taken my boards yet, I confidently said "no" and undaunted, she said "Well as a future general pediatrician who is on the frontlines diagnosing and treating children, I want you to partner with me in co-editing a textbook." That was the really the beginning of a beautiful friendship as we spent hours upon hours writing, editing, and talking about medicine, science, life, and the future of the Red Sox.

Unfortunately when I turned in my first chapter to her on gastrointestinal bleeding, she greeted that moment with memorable statement \#3- "Have you ever tried to write anything?" Wow! Did I ever learn how to write over the next few years as we published two editions of the textbook Pediatric Medicine.

In fact with Mel's guidance, I got more and more interested in figuring out how to take the science of pediatrics and translate it into a life-long educational agenda for all those vested in caring for children and began to develop my interest if not passion for medical education. In fact Mel encouraged my role as a teacher in what was then the New Pathway at Harvard Medical School. With Mel always wanting to hear how and what I was teaching, I had found my niche as an academic generalist and educator. In fact Mel thought so too and thus came memorable statement \#2-“I know you will be one of those select few who never leaves Boston Chil- dren's." Well I'm sure at this point we all realize she is a much better scientist and mentor than a fortune teller-at least with me.

Because right after she said that I got the call from Jerry Lucey to consider coming to Vermont and when I told Mel that I was really interested in going there, she smiled and undaunted said in memorable comment \#1, "I hear the maple syrup there is really great!"

Well Mel-it is you who are great and tonight on behalf of all the students, residents, fellows, peers, children and families you have touched in one way or another, I want to thank you for all that you have done and continue to do and congratulate you on this wonderful honor of the Howland Award!

But if words will not convince you what a special person Mel is - maybe a song will-(sung to the tune of the Broadway song "Mame"-lyrics rewritten by me)

You helped the tiniest infants survive-Mel

You made neonatology thrive-Mel

You've mentored thousands of trainees

And given us advice that's always right.

You've smartened all of our brainees

And helped us set our goals and hit new heights!

Tonight we all just want to say wow-Mel

You've earned the award we fondly call How-Mel

Your many contributions

Have helped children who are sick and who are well.

We owe so much to what you've done

From you we've learned at least a ton

To us you're truly number one-here's to Mel!

Lewis R. First, M.D.

Professor and Chair

Department of Pediatrics

University of Vermont College of Medicine

As one of three friends fortunate to have been invited to salute Mel this evening, we were admonished by Peggy Hostetter $\{v i a$ en e-mail that reached me in Tanzania! $\}$ that "the goal is gentle humor, nor corruscation or canonization." To avoid the latter is difficult, but I shall try. In reviewing my friendship with Mel, two themes predominate. The first obviously focuses on neonatology and the wondrous transition from intrauterine and adaptation to extrauterine life. The second is the recognition and provision of equal opportunities for women, in science, and in all endeavors. The John Howland award recognizes the first, but it is worth noting that in a field blessed with an abundance of stellar women, she is only the sixth woman awardee among 53 recipients honored since its establishment in 1952. I shall focus then on the second theme: women's roles.

Mel attended a women's college, Wheaton in Massachusetts, where she majored in chemistry. In later years, to her regret, Wheaton succumbed to the trends of the time and became co-educational. Whether true or apocryphal, I am uncertain, but it is rumored that she was later offered the opportunity to assume the Presidency of her alma mater but declined because it was no longer truly a women's college. With personal certainty I can relate to you the only occasion on which I 
remember her chiding me - that none of Cathy's and my five daughters had attended a women's college, but each chose a coeducational institution. It was an unacceptable excuse that they, not their parents, had made the choices.

The second institution at which she pursued studies and launched her medical career was the John Hopkins Medical School, not only coeducational but widely recognized for its leadership in the provision of opportunities for women in medicine. There she later mentored her initial disciples in neonatology. It may be appropriate at this point to explain to the younger generation among you, who did not receive a compulsory background in Greek and/or Latin studies, that Mentor was the comrade of Odysseus to whom he entrusted the education of his son Telemachus when the father went off to the Trojan War and subsequently spent 10 adventurous years wending his way home. Of special relevance to Mel's role is the belief that Mentor was really the Goddess Athena in disguise!

One of Mary Ellen's initial Hopkins fellows was George Brumley who later blessed us for 13 years as our Chief of Neonatology at Duke. Our chief resident suggested that at the commencement of George's daily ICN rounds, the house officers be equipped with indwelling Foley catheters! Undoubtedly the meticulous thoroughness of these sessions was a reflection of his apprenticeship with Mel.

Many of the women $\{$ as well as the men $\}$ who benefited from her tutelage are here with us tonight and can attest to the attention and inspiration provided by our awardee. Recently her accomplishments were recognized by election to the Presidency of the triple AAAS. Her presidential address, entitled "What is Good for Children is Good for Mankind" at one point left me a bit disgruntled when she called for "ways to prevent epidemics and control the spread of infection, even in the absence of appropriate vaccines". However this was but a momentary aberration as she then proceeded to reveal her familiarity with the work of another contemporary achiever, J.K. Rowling, whose Harry Potter novels Mel stated have "captivated individuals from 8 to 80 years of age." Mary Ellen then revealed that she knows the Edinburgh Neonatologist who had attended the birth of Ms. Rowling's infant. She had attempted unsuccessfully to lure him and the author to speak at the AAAS meetings. Also she called attention to her awareness of a new pediatric ailment, "Hogwarts headaches" described in a recent letter to the New England Journal of Medicine.

On only a single occasion have I found Mel in error. Recently I received an anguished e-mail from an old friend, Thomas Eliot Frothingham, requesting that I put him in touch with Dr. Avery. Apparently, according to Tom, she and others at Harvard Medical School have persisted in the erroneous pronunciation of her chair, the Thomas Morgan Rotch \{correctly pronounced roach $\}$ professorship which they mispronounce as the Thomas Morgan Rotch \{mistakenly pronounced crotch $\}$ professorship, a rhyme which is a source of consternation and embarrassment to the descendants of that early Harvard pediatrician. If that is the worst transgression of our friend and awardee, then her reputation for accuracy is hardly tarnished. We can all join in saluting her on this happy occasion-To our Athena-congratulations, long life and happiness.
Samuel L. Katz, M.D. Wilburt C. Davison Professor \& Chairman Emeritus Department of Pediatrics Duke University Medical Center 